\title{
Front Matter: Volume 11880
}

, "Front Matter: Volume 11880," Proc. SPIE 11880, Emerging Applications in Silicon Photonics II, 1188001 (20 October 2021); doi: 10.1117/12.2616707

SPIE. Event: SPIE Photonex, 2021, Glasgow, Scotland, United Kingdom 


\title{
PROCEEDINGS OF SPIE
}

\section{Emerging Applications in Silicon Photonics II}

\author{
Callum G. Littlejohns \\ Marc Sorel \\ Editors
}

\section{8-30 September 2021 \\ Glasgow, United Kingdom}

Sponsored by

Leybold (Germany)

Scanwel (United Kingdom)

Laser Components (Germany)

iXblue (France)

Glasgow City Council (United Kingdom)

Glasgow Convention Bureau (United Kingdom)

Cooperating Organizations

Photonics21 (United Kingdom)

Fraunhofer UK Research Ltd. (United Kingdom)

Future Photonics Hub (United Kingdom)

Knowledge Transfer Network (United Kingdom)

CENSIS (United Kingdom)

Association of Industrial Laser Users (United Kingdom)

Technology Scotland (United Kingdom)

Photonics Leadership Group (United Kingdom)

Published by

SPIE 
The papers in this volume were part of the technical conference cited on the cover and title page. Papers were selected and subject to review by the editors and conference program committee. Some conference presentations may not be available for publication. Additional papers and presentation recordings may be available online in the SPIE Digital Library at SPIEDigitalLibrary.org.

The papers reflect the work and thoughts of the authors and are published herein as submitted. The publisher is not responsible for the validity of the information or for any outcomes resulting from reliance thereon.

Please use the following format to cite material from these proceedings:

Author(s), "Title of Paper," in Emerging Applications in Silicon Photonics II, edited by Callum G. Littlejohns, Marc Sorel, Proc. of SPIE 11880, Seven-digit Article CID Number (DD/MM/YYYY); (DOI URL).

ISSN: 0277-786X

ISSN: 1996-756X (electronic)

ISBN: 9781510646049

ISBN: 9781510646056 (electronic)

Published by

SPIE

P.O. Box 10, Bellingham, Washington 98227-0010 USA

Telephone +1 3606763290 (Pacific Time)

SPIE.org

Copyright (C) 2021 Society of Photo-Optical Instrumentation Engineers (SPIE).

Copying of material in this book for internal or personal use, or for the internal or personal use of specific clients, beyond the fair use provisions granted by the U.S. Copyright Law is authorized by SPIE subject to payment of fees. To obtain permission to use and share articles in this volume, visit Copyright Clearance Center at copyright.com. Other copying for republication, resale, advertising or promotion, or any form of systematic or multiple reproduction of any material in this book is prohibited except with permission in writing from the publisher.

Printed in the United States of America by Curran Associates, Inc., under license from SPIE.

Publication of record for individual papers is online in the SPIE Digital Library.

\section{SP|E. DIGITAL}

Paper Numbering: A unique citation identifier (CID) number is assigned to each article in the Proceedings of SPIE at the time of publication. Utilization of CIDs allows articles to be fully citable as soon as they are published online, and connects the same identifier to all online and print versions of the publication. SPIE uses a seven-digit CID article numbering system structured as follows:

- The first five digits correspond to the SPIE volume number.

- The last two digits indicate publication order within the volume using a Base 36 numbering system employing both numerals and letters. These two-number sets start with 00, 01, 02, 03, 04, 05, 06, 07, 08, 09, 0A, OB ... 0Z, followed by 10-1Z, 20-2Z, etc. The CID Number appears on each page of the manuscript. 


\section{Contents}

EMERGING APPLICATIONS IN SILICON PHOTONICS I

1188006 Camera-based metrology of subwavelength scatterers in photonic integrated circuits [1 1880-23]

EMERGING APPLICATIONS IN SILICON PHOTONICS II

11880 OA Developing optomechanical inertial sensors (Invited Paper) [1 1880-8]

EMERGING APPLICATIONS IN SILICON PHOTONICS III

11880 OF Fabrication tolerant design of silicon nitride Kerr comb generators [1 1880-13]

H2020 PICTURE PROJECT

$11880 \mathrm{Ol} \quad$ Wide-wavelength range AIGalnAs laser array achieved by selective area growth on heterogenerous InP-on-Si wafer (Invited Paper) [11880-15]

$11880 \mathrm{OL} \quad$ Electro-optic co-design for next generation silicon optical transmitters (Invited Paper) [11880-18]

$118800 \mathrm{M} \quad$ Novel technology of III-V die-bonded SOI photonic integrated circuits (Invited Paper) [11880-19] 
Proc. of SPIE Vol. $118801188001-4$

Downloaded From: https://www.spiedigitallibrary.org/conference-proceedings-of-spie on 25 Apr 2023
Terms of Use: https://www.spiedigitallibrary.org/terms-of-use 